\title{
Transposition
}

Musique et Sciences Sociales

\section{Esteban Buch, Igor Contreras Zubillaga \& Manuel Deniz Silva (eds), Composing for the State: Music in Twentieth-Century Dictatorships}

Abingdon, Routledge, 2016.

\section{Lindsay Carter}

\section{OpenEdition}

Journals

Electronic version

URL: http://journals.openedition.org/transposition/2629

DOI: $10.4000 /$ transposition.2629

ISSN: 2110-6134

Publisher

CRAL - Centre de recherche sur les arts et le langage

Electronic reference

Lindsay Carter, «Esteban Buch, Igor Contreras Zubillaga \& Manuel Deniz Silva (eds), Composing for the State: Music in Twentieth-Century Dictatorships », Transposition [Online], 7 | 2018, Online since 15 September 2018, connection on 25 September 2020. URL : http://journals.openedition.org/ transposition/2629; DOI : https://doi.org/10.4000/transposition.2629

This text was automatically generated on 25 September 2020

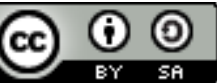

La revue Transposition est mise à disposition selon les termes de la Licence Creative Commons Attribution - Partage dans les Mêmes Conditions 4.0 International. 


\section{Esteban Buch, Igor Contreras Zubillaga \& Manuel Deniz Silva (eds), Composing for the State: Music in Twentieth-Century Dictatorships}

Abingdon, Routledge, 2016.

Lindsay Carter

\section{REFERENCES}

Esteban Buch, Igor Contreras Zubillaga \& Manuel Deniz Silva (eds), Composing for the State: Music in Twentieth-Century Dictatorships, Abingdon, Routledge, 2016

1 Musical works written for dictatorial regimes bring complex ethical considerations for musicologists, performers, and listeners alike. Secondary literature about music in the Soviet Union and the Third Reich, in particular, has long since grappled with questions of how we should approach such works - whether this music should be performed, problems surrounding the intelligibility of politics in music, etc. - whilst primary sources reveal complex practices of self-fashioning that muddy any clear distinction between private and public or resistance and complicity. Composing for the State. Music in Twentieth-Century Dictatorships wades into these murky waters with suitable sensitivity. Described by the editors as a collection of micro-historical studies, the true value of this work is not in addressing long neglected issues, as the publication material suggests, but in its detailed study of the topic and its breadth of knowledge - its chapters span ten regimes and five decades, significantly widening the discussion beyond the two pillars of totalitarianism. It contains an impressive range of international scholarship that has hitherto been unavailable in English.

2 The collection takes a single-work approach, with each chapter focusing on a work for which the State played a role in the commission, production, execution or 
dissemination. These studies are separated into three sections: works composed for the people; works that are linked to the leader; and works that were commissioned for state commemoration events. Whilst the headings fit nicely for the last two sections, the links between the chapters in the first section and the title that joins them is somewhat less clear.

In this first section, Yannick Simon's fascinating chapter examines three productions from the Vichy regime that focus on the Joan of Arc myth. In doing so, Simon discusses questions of an 'official' style and the Vichy regime's involvement in music making, from commission to production. In outlining representations of Joan of Arc from before the Vichy takeover, the chapter demonstrates the adaptability of the martyr myth to suit differing political needs. Equally fascinating, is Hon-Lun Yang's excellent study of The East is Red (1964) in the People's Republic of China. Yang's vivid description of the stage settings provides a real sense of the scale of the production. As with Simon's chapter, it shows the extent of the State's involvement in the composition and production of the work and touches on the problems of an 'official' compositional aesthetics and on the refashioning and appropriation of history.

of note in the second section is Marina Frolova-Walker's fascinating chapter on Shostakovich's Song of the Forests (1949), which calls for a re-Stalinisation of the work after previous whitewashing. Frolova-Walker presents an analysis that highlights both explicit and implicit references to Stalin, including intertextual references to film scores, and convincingly concludes that the work cannot be divorced from its context by simply removing explicit references from the text. Elsewhere in this section, Katherine L. FitzGibbon discusses Gottfried Müller's Deutsches Heldenrequiem (1934), which was dedicated to the Fürer, Justine Comtois examines Alfred Casella's opera dedicated to Mussolini, Il deserto tentato (1937) and Andrzej Tuchowski provides a semantical analysis of Alfred Gradstein's A Word About Stalin.

5 Running throughout the book we see tales of the refashioning of history. This is addressed most strongly in the final section on works that were commissioned for state commemorations. The three chapters fit nicely together, all touching on retrospective readings of the works. Manuel Deniz Silva outlines why Luis de Freitas Branco's Solemn Overture 1640 (1939) has puzzled biographers, due to the composer's political stance, and presents a nuanced explanation of why the composer accepted the commission and why the music appears to be stylistically out of place amongst Branco's other works. Moving on from this, Igor Contreras Zubillaga's article on the Concierto de la Paz provides a wonderful addition to the collection, discussing the 'non-propagandistic' policies surrounding the event, concluding that in this instance the aim to present 'objective fact' was a political statement itself. And finally, Esteban Buch looks at the problematic aspects of Alberto Ginastera's Iubilum, a work commissioned to celebrate the founding of Buenos Aires. Buch highlights the clash of Indian and Catholic themes in the work and the ultimate triumph of Christianity over indigenous cultures. $\mathrm{He}$ concludes that whilst this does not equal an endorsement of the massacre of the Indians that took place, it does ignore the violence that allowed Christianity to emerge victorious.

6 The volume stops short of questions of comparison - the editors state as much in the introduction - distancing themselves from issues surrounding the term totalitarianism. However, as an edited collection that places music from a variety of regimes under one umbrella term, inevitable similarities and points of departure do emerge. In fact, the 
claim that the selection demonstrates a variety of institutional traditions is a point of comparison itself. Similar aesthetic considerations emerge in many of the chapters such as monumentality, accessibility, nationality, religiosity, and continuity with and refashioning of the past. Each of the works discussed was intended to be a 'great' work of art but time and again we see encounters between music and the State bring about uncertain results, not least due to vague policies on 'official' musical aesthetics.

7 One of the key ethical and theoretical considerations to emerge across the book is the post facto reception of the works. Time after time, we see attempts to distance the music from its political context - Müller called the Deutsches Heldenrequiem a personal statement of grief and references to Stalin were removed from Shostakovich's Song of the Forest after the dictator's death. Instead, the introduction of this book poses these works of art as 'aesthetic documents' of barbarism; and whether or not we choose to listen to and perform the music, the chapters in this collection help to set the record straight about the relationship between music and politics in an admirable number of contexts.

\section{AUTHORS}

\section{LINDSAY CARTER}

Lindsay Carter is a PhD candidate at the University of Bristol. Her thesis examines film music in the Soviet Union and the Third Reich (with particular emphasis on music as a site for the performance of ideology in film) and spans musicology, film studies and cultural history. Beyond this, her research interests include Twentieth-century music and politics, film music and narratology, opera and film, and musical intertextuality. Her recent publication, on musical gags and the problems of comedy in Stalinist cinema, appeared earlier this year in the Germanlanguage collection Musik in der Filmkomödie. 